\title{
THE IMPACT OF A CIVIL WAR ON EDUCATIONAL DEVELOPMENT: THE CASE OF SIERRA LEONE
}

\author{
Malika Sahel $^{1}$

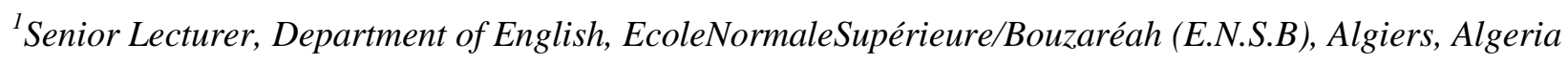

\begin{abstract}
Once independent in 1961, Sierra Leone set up educational development as her first target to start her long way towards progress and international standards. However, the achievement of this crucial objective was hampered by different conflicts this African country experienced. For instance, the 1991 Civil War forced Sierra Leonean youth to take up arms and lose their formal education, and skills passed down from fathers to sons in agriculture. Many children did not go to school because schools were either destroyed or shut down.
\end{abstract}

Keywords: Sierra Leone, Civil War, Impact, Education, Child Soldier.

\section{INTRODUCTION}

During the Civil War (1991-2002), many Sierra Leoneans left their hometowns in order to seek a safe shelter from the horrors of the war and others remained in Freetown, hoping of a better future in the city. In fact, in the absence of the rudimentary requirements like water, sanitation and electricity throughout most of the country, people's struggle was just limited to survive. However, once the war ended, security, political, economic and social rehabilitation significantly progressed in an attempt to rebuild what was destroyed. It is obvious that the effects of this war on different sectors were disastrous, particularly on Education which has constituted the cornerstone of any national development.

The present paper attempts to assess the impact of the Sierra Leonean Civil War on educational development. The latter has been identified as the first priority since independence (1961) to fight ignorance, poverty and underdevelopment. To what extent did the Civil War hamper educational progress in Sierra Leone ? What were the most important policy measures taken to push forward the educational machinery to overcome the imposed disaster in order to restart with more confidence the building up of a strong independent Sierra Leone?

Before considering the impact of the Civil War on educational development in Sierra Leone, it is interesting to refer to the damage the Civil War caused to Public Infrastructures there.

\section{PUBLIC INFRASTRUCTURES DURING THE}

\section{CIVIL WAR}

The Civil War in Sierra Leone had a tremendous effect on the Public Infrastructures. More than two thousands and five hundreds villages and towns throughout the country and over six thousands private houses in Freetown alone were demolished.[1] The limited trunk and feeder road networks were damaged, various roads in and around the capital city linking the centre to the east of the country deteriorated. Most of the rural areas became inaccessible, a fact that limited the movement of both people and goods. Furthermore, economic and social infrastructures were largely destroyed, leading to an economic decline.[2]For instance, the consequence of the 1977 May Coup and the Revolutionary United Front invasion of Freetown in January 1999 which resulted in massive socio-economic infrastructures destruction worsened the economic situation.[3]In this context, it was pointed out that by the year 2000, Sierra Leone national income per capita rapidly depreciated to under \$140.[4]This widespread destruction which armed violence caused, prevented the government from mobilizing domestic resources and reduced average household income. Moreover, many civilians in Freetown, for instance, in 1997-1998, were afraid to leave their houses because they risked being shot.[5]Besides, business people were unable to carry their business for a long period and shopkeepers remained closed much of the time and had to consume their own stocks in order to survive or avoid being robbed.

Thus, internal conflicts increased poverty and postponed prospects for developments.[6]During the 1990's, the manifested attempts to implement reforms were held back by armed violence and consequent political instability. This period of uncertainty in which education was negatively affected and totally deteriorated, marked the Sierra Leonean people who witnessed at Independence (1961) their Government's determination to tackle educational development as a first priority in order to progress. Yet, this target was made even more difficult to attain by the different conflicts this West African country experienced. Many youths lost their formal education, many children did not attend school because schools were either demolished or shut down. In this respect, it was reported that the constituent colleges of the university, one hundred and seventeen primary, seventy secondary and thirty two vocational institutions were damaged.[7] 


\section{THE EDUCATIONALDEVELOPMENT: A CIVIL WAR VICTIM}

In 1997, tension in Sierra Leone was so high that children could not attend schools for a whole academic year. This, in fact, engendered serious educational gaps that created other social problems. Indeed, by the end of the conflict, a considerable number of school-going children had outgrown school age while many others had lost two to three years of schooling.[8]Consequently, in 2001, a survey entitled the National School Survey Report, identified 3,152 with a total number of 4,854 school buildings.[9]The survey revealed 52 percent of the classrooms needed to be repaired or reconstructed, 35 percent needed full reconstruction while only 13 percent were useful but in bad conditions.[10]

This lack of appropriate schools coupled with the inherited lack of the needed qualified teachers hampered the educational development in Sierra Leone and damaged the social growth since illiteracy increased. For instance, illiteracy among children of 10 years and more was 60 percent. In 2003, for instance, there were between 350 and 400,000 children who were out of school. It was reported that in mid-2003, 38 percent of females and 31 percent of males aged between 5 and 17 lacked formal education. This situation revealed around 570,000 school-aged children have never been to school: 315,000 females and 255,000 males.[11]In this context, Abel Ngafua, principal of a primary school in Dawa, on the border with Liberia, testified: "It was terrible. There was no school in this area for 12 years during the war."[12]Besides,the Civil War displaced almost one third of the country's population and teachers were among those who migrated. The provision of free education motivated teachers to prefer teaching in the provinces and remote rural areas. Accordingly, once the conflict ended, disequilibrium in the concentration of teachers in certain areas became a reality, leading to different literacy rates in different regions of Sierra Leone. For instance, in 2004, while literacy rate in the Eastern and Northern Regions was only 31 percent respectively and in Southern Region 34 percent, in the Western Area it reached 65 percent.[13]

During the colonial era, Sierra Leone was one of the first West African countries to have a university, Fourah Bay College. However, the country's literacy rate has remained one of the lowest in the world. Sierra Leone was ranked $119^{\text {th }}$ out of 177 countries surveyed for the combined enrolment in primary, secondary and tertiary education.[14]Such an alarming educational situation was caused by several factors among these one can cite the teachers' very low wages and the bad working conditions for educational institutions' staff. Indeed, schools were neglected and the quality of teaching was generally poor. Moreover, the cost of education was very expensive. The very high tuition fees and other costs handicapped the poor families, which constituted the bulk of the country's population, and prevented them from sending their children to schools. Seventy percent of the population was living in poverty.[15]For instance, in Bo, many families could not afford the cost of education for their children. Furthermore, the general lack of water and electricity supply in the country made study facilities too difficult for the majority of school-going children. Most of the students were studying only during the day. Candle lights, paraffin lit lamps and particularly in rural areas, cooking fires remained the only afford sources for reading and studying. Besides, university students as well as lecturers and scientists who needed experimentations and exercises that required electricity were blocked and could not progress in the absence of rudimentary conditions.

Indeed, in the whole country, electricity was insufficiently provided in general. High level illiteracy was also caused by the displacement of the population, a fact the Civil War imposed. In this context a Sierra Leonean student testified:

I was attending Christ the King College when the war broke out: I was in Form Three. I went for holidays to my village.... Rebels attacked my village, burnt our houses, looted our property and killed... my father, my sister and her husband. These people were the ones paying my school fees... I want to continue my education but there is no one to support me as my sister and her husband who supported me are dead.[16]

Thus, the Civil War imposed on Sierra Leonean children the most violent aspects of human cruelty at an age they were in most need for love, care and appropriate conditions to grow as normal human beings, offered education and full human rights.

Indeed, instead of offering children a descent life and sending them to school, both government and rebel forces used children as soldiers in Sierra Leone civil war. Different estimates of their number were revealed. The Children's Right Organisation UNICEF estimated their number to 5,000.[17]The office of the United Nations Kingdom Special Representative for Children put the number at 10,000.[18]Another estimate pointed out that children soldiers composed 40-50 percent of the Revolutionary United Front's, 15,000 forces and 20 percent of the Sierra Leonean government's 25,000 member civil defence forces.[19]

Children soldiers were often preferred to be used because children were fearless, obedient, easily manipulated and did not ask for compensation. In this context, a Sierra Leonean who worked with former child soldiers described them:

[They] were very scary, more erratic and more violent than most fighters. They obeyed any order, no matter how brutal.... Unlike adults, children did not negotiate with the enemy or take bribes... they did not form factions or take up arms against you, and they were more easily controlled. Kids just wanted to be loved, if not by a parent, then a rebel commander.[20]

In fact, improvements in military technology facilitated the use of this young generation. Guns, such as the Soviet-made 
AK-47 or the American M-16, were simplified and could be stripped and gathered by children as young as 10 years old. These rifles were cheap and easily obtained in some parts of Africa for less than \$ 6 each.[21]A Human Rights Watch reported : "Child combatants armed with pistols, rifles and machetes actively participated in killing and massacres .... Often under the influence of drugs, they were known for their impuriosity, lack of control and brutality".[22]

Many children joined the army because they lost hope. The absence of any hope to keep their moral up trapped them. They were exposed to unemployment and disillusionment. Fighting in the war seemed an alternative to break out of their despair and change their lives and feel safe. Many of them aligned themselves with one or more of the factions and achieved what they considered evolution : they managed to acquire wealth, status and friendliness in arms that would have been unattainable.[23]Thus, poverty and insecurity urged children to join the army. In this context, a child soldier claimed the problem that is affecting us children is the war that forces us to run away our homes, lose our families and aimlessly roam the forest. As a result, we get involved in the conflict as soldiers, carriers of loads and in many other difficult tasks. All this is because of starvation, the loss of our families, and the need to feel safe and be part of something when all else has broken down. I joined the army really because of the loss of my family and starvation. I wanted to avenge the death of my family. I also had to get some food to survive, and the only way to do that was to be part of the army. It was not easy being a soldier, but we just had to do it.[24]

This alarming situation which drove children to the most cruel circumstances and prevented them from having access to education was ended and measures were taken in favour of poor children. Indeed, once the conflict disappeared and turbulences ended, policy measures including the abolition of tuition fees and school feeding were implemented. Consequently, the total number of enrolled pupils tripled in less than four years. Yet, many could not succeed to reach Grade II and left school. The latter lacked the needed qualified number of teachers to accompany the considerable increase in the pupil's enrollment. This teachers' shortage faced by the educational institutions constituted a serious obstacle to any kind of development targeted by professional standards.

In fact, this same educational problem prevailed in the first years after Sierra Leone independence. In this context, the British Council's Annual Report for 1964/1965 pointed out :

While Sierra Leone was above the average per capita African figure for primary school places which rose from 35,000 in 1953 to 103,000 in 1963 , the problem of maintaining sound professional standards was an overwhelming one. While the primary system was expanding at an average of about 10,000 pupils a year, the percentage of trained teachers has actually fallen from 50 to 39.[25]
The educational field in 1964, witnessed the most important achievement: Njala University College was opened with 101 students. Moreover, the 'Development Programme in Education for Sierra Leone, 1964-1970", prepared by Dr. G. F. Slight of the UNESCO was submitted. However, the economic situation continued to deteriorate.[26]It even became more complicated after the civil war which resulted in the destruction of the public infrastructures, worsened the life of the people, increased illiteracy, and made many orphans, beggars, thieves and murderers. This bad social reality was further nourished by school failure which was mainly caused by the teachers' shortage in the educational institutions.

For instance, in 2003 Fiscal year, the Ministry of Finance staffing ceiling for all teaching staff supported by the Ministry of Education, Science and Technology (MEST) amounted to 25,000 . The total number on the payroll in December 2003 was only 21,213 . This meant 15 per cent less than the ceiling and nearly 7 per cent less than the total payroll in September 2001. Consequently, the ceiling was augmented to 28,000 for 2004 Fiscal year.[27]The National Recovery Committee registered a total of 19,700 teachers working in primary schools in May 2003. Seven months later, only 16,059 primary teachers were on the government payroll. During the same month of the same year (2003), a total of 5,048 secondary teachers at 240 schools were on the government payroll. About 40 per cent were at 49 schools in Freetown and another quarter was at schools in Bo and Kenema Districts. Koinadugn District had only six secondary schools with only 55 payroll teachers. [28]

As in any underdeveloped country, the prevailing illiteracy affected girls more than boys. Girls constituted only 42 per cent of pupils in primary education. Of those aged 10 years and older, only 39 per cent were literate.[29]At university level, females constituted 19 percent of the university students.[30]In fact, the literacy rate varied according to age, gender and region. While half of the male population was literate, only 29 per cent of the female population could read and write. Moreover, literacy rates in western area were twice higher than those in the other regions. Educational achievement by the population was very low, with an average of less than two years for females and less than four years for males (fifteen years old or older). For instance, in 2004, illiteracy among the men was 50 percent whereas it was 70 per cent among women. Moreover, while in Western area, it was 34 per cent, in Northern and Eastern Regions it was 68 per cent respectively, and in the Southern Region 65 percent.[31]

- [1] Appendix 2, part 4 : submissions, The Sierra Leone Civil Service - A Presentation to the TRC on Behalf of the All Peoples Congress (APC Party) presented by Hon. Wusu B. Munu.

- $\quad$ [2] Education in Sierra Leone Present Challenge, Future Opportunities, 27.

- [3] World Bank, 17th July, 2001, 1.

- [4] J. Ginifer, Armed Violence and Poverty in Sierra Leone, Centre for International Cooperation and 
Security, Department of Peace Studies, University of Bradford, March 2005.

- [5] World Bank, 17th July, 2001, 1.

- [6] Special Report, FAO, NFP Grop and Food Supply Assessment Mission to Sierra Leone, 15 January 1997.

- [7] J. Jonah, Economic Dimensions of the Conflict in Sierra Leone, 2004, p. 5.

- [8] Plan Ireland, Children in Disasters Programme, The Importance of Education in Disaster Rehabilitation The Rapid Education Programme in Sierra Leone", 2000 ; available at the following website :

www. Plan.ireland.org/pdfs/childerenindisasters.

- [9] National School Survey Report (NSSR), 2001, as cited in World Bank, Project Appraisal Document for Rehabilitation of Basic Education ; 2003.

- [10] "NSSR - Sierra Leone Report of 2001".

- [11] Sierra Leone Status Report on Youth and Adult Education Issues, Trends, Challenges prepared for the Confinitea via African Preparatory Conference Nairobi : 5-7 November 2008. Theme : "The Power of Youth and Adult Learning for Africa's Development". www.uil.unesco.org Sierra Leone

- [12] Unicef 70 Years Child.www.unicef.org Reviving education in aftermath of Sierra Leone's Civil War /At a glance: Sierra Leone/Unicef.

- [13] Statistics Sierra Leonean Population Census 2004, from Education in Sierra Leone. Present Challenges, Future Opportunities, I, p.25.

- [14] United Nations High Commissioner for Refugees Sierra Leone Consolidating the Recovery and Reconstruction Process, Country Assessment Report, Under the Auspices of the AU/NEPAD sub-cluster on Post-Conflict Reconstruction and Development, Addis Ababa, Ethiopia, March 2008.

- [15] ChildFund, The Impact of Civil War in Sierra Leone. www.childfund.org Civil War in Sierra Leone/ChildFund.

- [16] D. Massakoi, TRC statement, Bo District, April 10th, 2003.

- [17] UNICEF 2000, Crisis in Sierra Leone Could Bring New Efforts to Recruit Children. www.unicef.org/newsline/00pr39.htm

- [18] UnitedNations 1999, Sierra Leone : 30 August - 4 September 1999.www.un.org/specialrep/childrenarmed-conflict/country visits.htm

- [19] B. Crossette, "Sierra Leone is No Place to be Young”, New York Times, February 1st, 1999, A1.

- [20] F. Douglas, "Children Forced to Kill”, Washington Post, April 8th, 2000.

- [21] UNICEF 1996, The State of World's Children 1996, www.unicef.org/sowc 96/

- [22] Ibid.

- [23] A. Rogers, TRC statement recorded in Kpala Chiefdom, Pujehum District, March 22nd, 2003.

- [24] I. Beah, A Long Way Gone : Memoirs of a Boy Soldier, (New York : Sarah Grichton Books, 2007), p. 199.
- [25] BW55/15, Confidential, The British Council, Sierra Leone, Representative's Annual Report19641965, 1965, p. 2.

- [26] BW55/15, Confidential, The British Council, Sierra Leone, Representative's Annual Report 19651966, 1966, p.1.

- [27] KPMG2003, in Teacher Motivation and Incentives in Sierra Leone, J. B. Harding and A. T. Mansary, Senior Lecturer, Division of Educational Studies, FBC, University of Sierra Leone, 2006, p. 5.

- [28] Ibid.

- [29] Statistics Sierra Leone Population Census 2004, op. cit.

- [30] Government of Sierra Leone : MDG Report for Sierra Leone, 2005.

- [31] Statistics Sierra Leonean Population Census 2004, op.cit.

\section{CONCLUSION}

In post-civil war Sierra Leone, many youths who did not succeed at school believed they were too old to return. They were to remain unqualified. Many of them were unemployed, begging and stealing to earn their living. These youths deserved a better future which only educational development could provide. Therefore, post-civil war education had to be recovered and teachers and pupils conditions had to be improved in a professional way. In fact, the restoration of the educational system in the injured nation had to focus on the construction and rehabilitation of damaged institutions without disregarding the provision of both teaching and learning resources including, teachers, materials and class rooms in order to allow a fruitful functioning of the educational machinery. The latter has remained the cornerstone for any targeted national development and progress.

\section{REFERENCES}

[1]. Beah I., A Long Way Gone : Memoirs of a Boy Soldier, (New York : Sarah Grichton Books, 2007).

[2]. Crossette B., "Sierra Leone is No Place to be Young", New York Times, February $1^{\text {st }}, 1999$, A1.

[3]. Douglas F., "Children Forced to Kill”, Washington Post, April $8^{\text {th }}, 2000$.

[4]. Ginifer J., Armed Violence and Poverty in Sierra Leone, Centre for International Cooperation and Security, Department of Peace Studies, University of Bradford, March 2005.

[5]. Jonah J., Economic Dimensions of the Conflict in Sierra Leone, 2004.

[6]. Massakoi D., TRC statement, Bo District, April $10^{\text {th }}$, 2003.

[7]. Rogers A., TRC statement recorded in Kpala Chiefdom, Pujehum District, March 22 $2^{\text {nd }}, 2003$.

[8]. Appendix 2, part 4 : submissions, The Sierra Leone Civil Service - A Presentation to the TRC on Behalf of the All Peoples Congress (APC Party) presented by Hon. Wusu B. Munu.

[9]. BW 55/15, Confidential, The British Council, Sierra Leone, Representative's Annual Report1964-1965, 1965. 
[10]. BW 55/15, Confidential, The British Council, Sierra Leone, Representative's Annual Report 1965-1966, 1966.

[11]. ChildFund, The Impact of Civil War in Sierra Leone. www.childfund.org Civil War in Sierra Leone/ChildFund.

[12]. Education in Sierra Leone Present Challenge, Future Opportunities.

[13]. Government of Sierra Leone : MDG Report for Sierra Leone, 2005.

[14]. KPMG 2003, in Teacher Motivation and Incentives in Sierra Leone, J. B. Harding and A. T. Mansary, Senior Lecturer, Division of Educational Studies, FBC, University of Sierra Leone, 2006.

[15]. National School Survey Report (NSSR), 2001, as cited in World Bank, Project Appraisal Document for Rehabilitation of Basic Education ; 2003.

[16]. "NSSR - Sierra Leone Report of 2001".

[17]. Plan Ireland, Children in Disasters Programme, The Importance of Education in Disaster Rehabilitation - The Rapid Education Programme in Sierra Leone”, 2000 ; available at the following website :

www. Plan.ireland.org/pdfs/childerenindisasters.

[18]. Sierra Leone Status Report on Youth and Adult Education Issues, Trends, Challenges prepared for the Confinitea via African Preparatory Conference Nairobi : 5-7 November 2008. Theme : "The Power of Youth and Adult Learning for Africa's Development”. www.uil.unesco.org Sierra Leone

[19]. Special Report, FAO, NFP Grop and Food Supply Assessment Mission to Sierra Leone, 15 January 1997.

[20]. Statistics Sierra Leonean Population Census 2004, from Education in Sierra Leone. Present Challenges, Future Opportunities, I.

[21]. Unicef 70 Years Child.www.unicef.org Reviving education in aftermath of Sierra Leone's Civil War /At a glance : Sierra Leone/Unicef.

[22]. UNICEF 1996, The State of World's Children 1996, www.unicef.org/sowc 96/

[23]. UNICEF 2000, Crisis in Sierra Leone Could Bring New Efforts to Recruit Children. www.unicef.org/newsline/00pr39.htm

[24]. United Nations 1999, Sierra Leone : 30 August - 4 September 1999.www.un.org/specialrep/children-armedconflict/country visits.htm

[25]. United Nations High Commissioner for Refugees Sierra Leone Consolidating the Recovery and Reconstruction Process, Country Assessment Report, Under the Auspices of the AU/NEPAD sub-cluster on PostConflict Reconstruction and Development, Addis Ababa, Ethiopia, March 2008.

[26]. World Bank, 17 $7^{\text {th }}$ July, 2001.

\section{BIOGRAPHY}

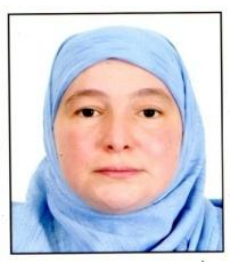

Dr. Malika SAHEL is a Senior Lecturer of British Civilization in the Department of English at the 'EcoleNormaleSupérieure of Bouzaréah (E.N.S.B) in Algiers/Algeria. 